\title{
Receptor-Mediated Muscle Homeostasis as a Target for Sarcopenia Therapeutics
}

\author{
Jong Hyeon Yoon ${ }^{1,2}$, Ki-Sun Kwon ${ }^{1,2,3}$ \\ ${ }^{1}$ Aging Research Center, Korea Research Institute of Bioscience and Biotechnology (KRIBB); ${ }^{2}$ Department of Functional \\ Genomics, KRIBB School of Bioscience, Korea University of Science and Technology; ${ }^{3}$ Aventi Inc., Daejeon, Korea
}

Sarcopenia is a disease characterized by age-related decline of skeletal muscle mass and function. The molecular mechanisms of the pathophysiology of sarcopenia form a complex network due to the involvement of multiple interconnected signaling pathways. Therefore, signaling receptors are major targets in pharmacological strategies in general. To provide a rationale for pharmacological interventions for sarcopenia, we herein describe several druggable signaling receptors based on their role in skeletal muscle homeostasis and changes in their activity with aging. A brief overview is presented of the efficacy of corresponding drug candidates under clinical trials. Strategies targeting the androgen receptor, vitamin D receptor, Insulin-like growth factor-1 receptor, and ghrelin receptor primarily focus on promoting anabolic action using natural ligands or mimetics. Strategies involving activin receptors and angiotensin receptors focus on inhibiting catabolic action. This review may help to select specific targets or combinations of targets in the future.

Keywords: Sarcopenia; Muscle, skeletal; Aging; Drug therapy; Receptors, cell surface; Receptors, cytoplasmic and nuclear; Signal transduction; Molecular mechanisms of pharmacological action; Clinical trial

\section{INTRODUCTION}

Sarcopenia is an age-related skeletal muscle disorder. The term "sarcopenia" was first introduced in the 1980s to refer to an agerelated loss of lean body mass that affects mobility, independence, and mortality [1]. In the past, there was a misconception that muscle loss with advancing age was an inevitable consequence of normal aging. Very recently, sarcopenia has been assigned to a new disease entity in the International Classification of Diseases, 10th and 11th revisions, although no drug has yet been approved for sarcopenia [2,3].

In 2010, the European Working Group on Sarcopenia in Older People (EWGSOP) published a working definition of sarco-

Received: 27 April 2021, Revised: 13 May 2021, Accepted: 15 May 2021

Corresponding author: Ki-Sun Kwon

Aging Research Center, Korea Research Institute of Bioscience and

Biotechnology (KRIBB), 125 Gwahak-ro, Yuseong-gu, Daejeon 34141, Korea

Tel: +82-42-860-4114, Fax: +82-42-861-1759, E-mail: kwonks@kribb.re.kr penia. The EWGSOP2 recommends a 4-step diagnostic approach, Find-Assess-Confirm-Severity (F-A-C-S), with the measurement of three parameters (muscle strength, muscle quantity/quality, and physical performance) as an indicator of severity $[4,5]$. The Asian Working Group has provided diagnostic strategies and cutoff values for Asian populations to facilitate the study of sarcopenia in Asian countries [6]. The International Clinical Practice Guidelines for Sarcopenia published in 2018 suggest strong recommendations for combination treatment involving physical training and protein supplementation as the primary treatment for sarcopenia [7].

Several clinical studies have shown the possibility of pharmacological interventions for sarcopenia $[8,9]$. For example, vita-

\section{Copyright $\odot 2021$ Korean Endocrine Society}

This is an Open Access article distributed under the terms of the Creative Commons Attribution Non-Commercial License (https://creativecommons.org/ licenses/by-nc/4.0/) which permits unrestricted non-commercial use, distribution, and reproduction in any medium, provided the original work is properly cited. 
min D supplementation had the beneficial effect of increasing muscle fiber size by $10 \%$ in elderly women [10]. Testosterone improved walking distance in men, although it had a risk of cardiovascular side effects [11]. Treatment with the myostatin inhibitor LY2495655 increased muscle mass and partially improved physical performance in elderly patients with weakened muscle strength [12]. In elderly individuals with sarcopenia, treatment with bimagrumab (BYM-338), an inhibitor of activin type II receptors, increased skeletal muscle mass [13,14].

In order to design an effective strategy for the treatment and prevention of sarcopenia, it is necessary to understand its mechanisms and signaling pathways [15]. Herein, we provide insights into potential targets to support the study of sarcopenia with a focus on pharmacological strategies.

\section{CELLULAR SIGNALING PATHWAYS AND MUSCLE AGING}

Most age-related factors contribute to the development of sarcopenia, and senile disorders such as cancer, arthritis, and chronic obstructive pulmonary disease are associated with a higher risk of the sarcopenic phenotype [16,17]. Aging impairs the balance between muscle anabolic and catabolic pathways, which leads to a gradual loss of muscle mass and function [18]. Insulin-like growth factor-1 (IGF-1), testosterone, exercise, $\beta 2$-adrenergic agents, and branched-chain amino acids are the major triggers of the anabolic pathway and are known to cause muscle hypertrophy through increased protein synthesis [19]. AKT/mammalian target of the rapamycin (mTOR) signaling activity induces phosphorylation of S6K and 4E-BP, leading to an increase in protein synthesis. AKT also regulates the initiation of translation through the glycogen synthase kinase $3 \beta$ (GSK3 $\beta$ )-eukaryotic translation initiation factor 2B (eIF2B) pathway [20-22]. Conversely, myostatin, glucocorticoids, oxidative stress (reactive oxygen species and nitric oxide), inflammatory cytokines (tumor necrosis factor alpha and interleukin 6 [IL-6]), and metabolic stress induce catabolic pathways, leading to muscle atrophy. The forkhead box $\mathrm{O}(\mathrm{FOXO})$ and nuclear factor- $\kappa \mathrm{B}$ pathways are crucial regulators of the expression of E3 ubiquitin ligases atrogin-1 and muscle RING-finger protein 1 (MuRF1), which play a dominant role in muscle atrophy. The activity of the FOXO transcription factor is regulated by AKT signaling $[23,24]$.

Muscular homeostasis involves a very complex network comprising multiple interconnected signaling pathways $[25,26]$. Unlike genetically induced or disease-related muscle disorders, the key cause of sarcopenia is aging. Therefore, understanding the molecular events caused by aging guides the direction of pharmacological interventions and helps to avoid unwanted adverse events.

\section{PHARMACOLOGICAL STRATEGIES FOR SARCOPENIA IN CLINICAL TRIALS}

Over the course of decades, dozens of clinical studies have been conducted on pharmacotherapy for sarcopenia, and the relevant information is easily accessible through ClinicalTrials.gov (Table 1, Fig. 1). There are several pharmacologically validated strategies, including anabolic steroids, exercise mimetics, nutrient supplements, myokines, and monoclonal antibody modulation. Numerous drugs target biological signaling pathways, and most of them are signaling receptors (Fig. 2). Systematic explorations and statistical analyses have often shown representative signal receptors that are likely to be targets for pharmacological interventions (Fig. 3).

Cellular signaling is usually transduced through four major types of receptors classified on the basis of their molecular structures and transduction mechanisms; ligand-gated ion channels, G-protein-coupled receptors (GPCRs), nuclear receptors, and receptor kinases [27]. These four major families of signaling proteins account for $44 \%$ of all human drug targets in the ChEMBL database. Moreover, $77 \%$ of small-molecule drugs target major signaling protein families (GPCRs 33\%, ion channels $18 \%$, kinases 3\%, and nuclear receptors 16\%) [28].

Intracellular receptors account for $10 \%$ to $15 \%$ of drugs on the market, including drugs that act on cytoplasmic receptors such as androgen receptors (ARs), estrogen receptors, progesterone receptors, and glucocorticoid receptors, and other drugs that act on nuclear receptors such as vitamin D receptor (VDR), thyroid hormone receptors, and peroxisome proliferator-activated receptors [27-30]. Ligands of intracellular receptors include lipophilic vitamins, steroid hormones, and small chemicals such as hydrogen peroxide and nitric oxide, which require membrane permeability for intracellular delivery [30,31]. There are several barriers to the intracellular delivery of therapeutic drugs, such as lysosome degradation and active efflux out of the cell. Lowmolecular-weight lipophilic compounds can diffuse directly into cells, whereas high-molecular-weight compounds usually need membrane transporters or endocytosis [32,33]. Proper entry into the cell and subsequent contact with the exact target lead to better therapeutic effects and reduce undesirable adverse effects [34]. 
Table 1. Current Status of Pharmacotherapies for Sarcopenia

\begin{tabular}{|c|c|c|c|c|c|}
\hline Sponsor & Drug & Target & Phases & Status & NCT number \\
\hline $\begin{array}{l}\text { Manchester University } \\
\text { NHS Foundation Trust }\end{array}$ & $\begin{array}{l}\text { Transdermal testosterone gel } \\
\text { (Testogel } 1 \% \text { ) }\end{array}$ & Androgen receptor & Phase 4 & Completed & NCT00190060 \\
\hline $\begin{array}{l}\text { The University of Texas Medical Branch, } \\
\text { Galveston }\end{array}$ & $\begin{array}{l}\text { Testosterone injection/ } \\
\text { Testosterone gel/Medrol }\end{array}$ & Androgen receptor & Phase 4 & Completed & NCT00957801 \\
\hline Gumi Cha Medical Center & Renamezin & Indoxyl sulfate (IS) & Phase 4 & Active, not recruiting & NCT03788252 \\
\hline Wake Forest University Health Sciences & Pioglitazone & $\operatorname{PPAR} \gamma$ & Phase 4 & Completed & NCT00315146 \\
\hline Erasmus Medical Center & Olimel N12 & Nutrition & Phase 4 & Recruiting & NCT04094038 \\
\hline University of Dundee & Allopurinol & Xanthine oxidase & Phase 4 & Completed & NCT01550107 \\
\hline Mahidol University & Vitamin D3 & Vitamin D receptor & Phase 3 & Unknown status & NCT02594579 \\
\hline $\begin{array}{l}\text { Washington University School of } \\
\text { Medicine }\end{array}$ & Testosterone & Androgen receptor & Phase 3 & Recruiting & NCT02938923 \\
\hline University of Nottingham & Sustanon 250 & Androgen receptor & Phase 3 & Active, not recruiting & NCT03054168 \\
\hline Kantonsspital Baselland Bruderholz & $\mathrm{K}$ citrate & Nutrition & Phase 3 & Completed & NCT00509405 \\
\hline RWTH Aachen University & $\begin{array}{l}\text { OLIMEL } 7,6 \% \text { E/PeriOLIMEL } \\
\text { 2,5\%E }\end{array}$ & Nutrition & Phase 3 & Not yet recruiting & NCT04012333 \\
\hline $\begin{array}{l}\text { Washington University School of } \\
\text { Medicine }\end{array}$ & DHEA & Androgen receptor & Phase 3 & Completed & NCT00205686 \\
\hline Indonesia University & Alfacalcidol & Vitamin D receptor & Phase 3 & Completed & NCT02327091 \\
\hline National Institute on Aging (NIA) & $\begin{array}{l}\text { Topical testosterone/ } \\
\text { Recombinant human growth } \\
\text { hormone }\end{array}$ & Androgen receptor & Phase 2 & Completed & NCT00183040 \\
\hline VA Office of Research and Development & $\begin{array}{l}\text { Testosterone enanthate/ } \\
\text { Finasteride }\end{array}$ & Androgen receptor & Phase 2 & Completed & NCT00475501 \\
\hline Regeneron Pharmaceuticals & REGN1033 (SAR391786) & Myostatin & Phase 2 & Completed & NCT01963598 \\
\hline Johns Hopkins University & Losartan & Angiotensin II receptor & Phase 2 & Completed & NCT01989793 \\
\hline University of Pennsylvania & Ghrelin & Ghrelin receptor & Phase 2 & Completed & NCT01898611 \\
\hline University of Regina & Creatine monohydrate & & Phase 2 & Unknown status & NCT03530202 \\
\hline Merck Sharp \& Dohme Corp & MK-0773 & Androgen receptor & Phase 2 & Completed & NCT00529659 \\
\hline Biophytis & BIO101 & Mas receptor & Phase 2 & Active, not recruiting & NCT03452488 \\
\hline Novartis Pharmaceuticals & Bimagrumab & Activin receptor & Phase 2 & Completed & NCT02468674 \\
\hline National Institute on Aging (NIA) & Androge/Anastrozole & $\begin{array}{l}\text { Androgen receptor/ } \\
\text { Aromatase }\end{array}$ & Phase 2 & Completed & NCT00104572 \\
\hline Sara Espinoza & Oxytocin nasal spray & Oxitocin receptor & Phase 1/Phase 2 & Completed & NCT03119610 \\
\hline University of Virginia & MK-677 & Ghrelin receptor & Phase 1/Phase 2 & Completed & NCT00474279 \\
\hline $\begin{array}{l}\text { The University of Texas Medical Branch, } \\
\text { Galveston }\end{array}$ & Rapamycin & mTOR & Phase 1 & Completed & NCT00891696 \\
\hline Mayo Clinic & Omega-3 & Nutrition & Phase 1 & Completed & NCT02103842 \\
\hline $\begin{array}{l}\text { The University of Texas Medical Branch, } \\
\text { Galveston }\end{array}$ & Insulin regular & Insulin/IGF receptor & Phase 1 & Completed & NCT00690534 \\
\hline Tufts University & Anamorelin hydrochloride & Ghrelin receptor & Phase 1 & Recruiting & NCT04021706 \\
\hline Seoul National University Hospital & $\mathrm{CPC}$ & Unknown & Early phase 1 & Unknown status & NCT02575235 \\
\hline
\end{tabular}

Data are presented for clinical trials in phase 1 development and higher, as available from Clinicaltrials.gov.

PPAR, peroxisome proliferator-activated receptor; DHEA, dehydroepiandrosterone; mTOR, mechanistic target of rapamycin; IGF, insulin-like growth factor; CPC, cetylpyridinium chloride. 


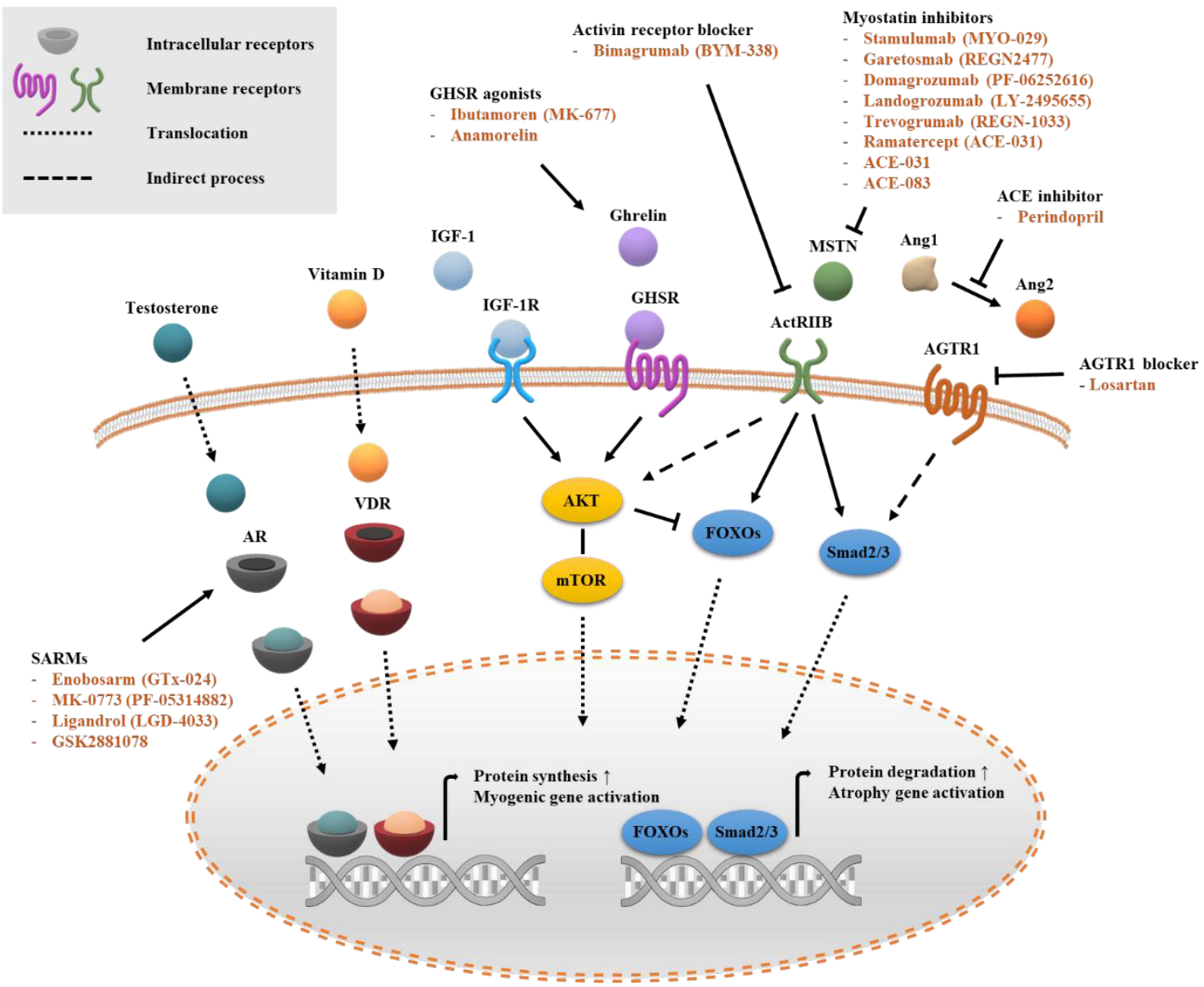

Fig. 1. Cell signaling pathways and pharmacological strategies for sarcopenia. GHSR, growth hormone secretagogues receptor or ghrelin receptor; IGF-1R, insulin-like growth factor 1 receptor; ACE, angiotensin-converting enzyme; ActRIIB, activin type II receptor; Ang1, angiotensin I; Ang2, angiotensin II; AGTR1, angiotensin II receptor type 1; SARM, selective androgen receptor modulator; AR, androgen receptor; VDR, vitamin D receptor; mTOR, mammalian target of the rapamycin; FOXO, forkhead box O.

\section{Proportion of target families}

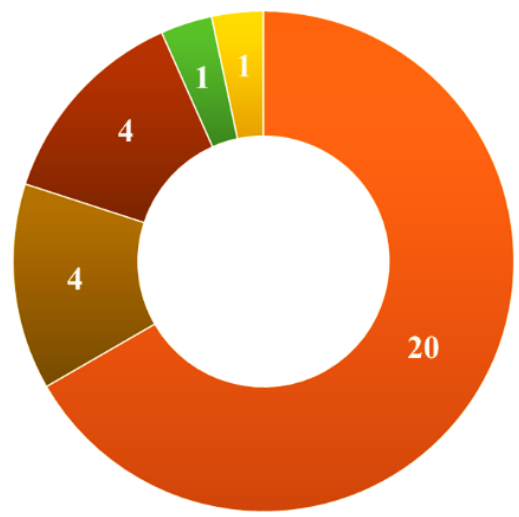

- Signaling molecule: receptors

- Signaling molecule: ligands

- Signaling molecule: effectors

- Nutrition

- Others (IS, XO, creatine, unknown)

Total $=\mathbf{3 0}$ ea

Fig. 2. Distribution of target families of small-molecule drugs in sarcopenia. Related data are described on ClinicalTrials.gov, and the figure includes data up to March 2021. IS, indoxyl sulfate; XO, xanthine oxidase. 


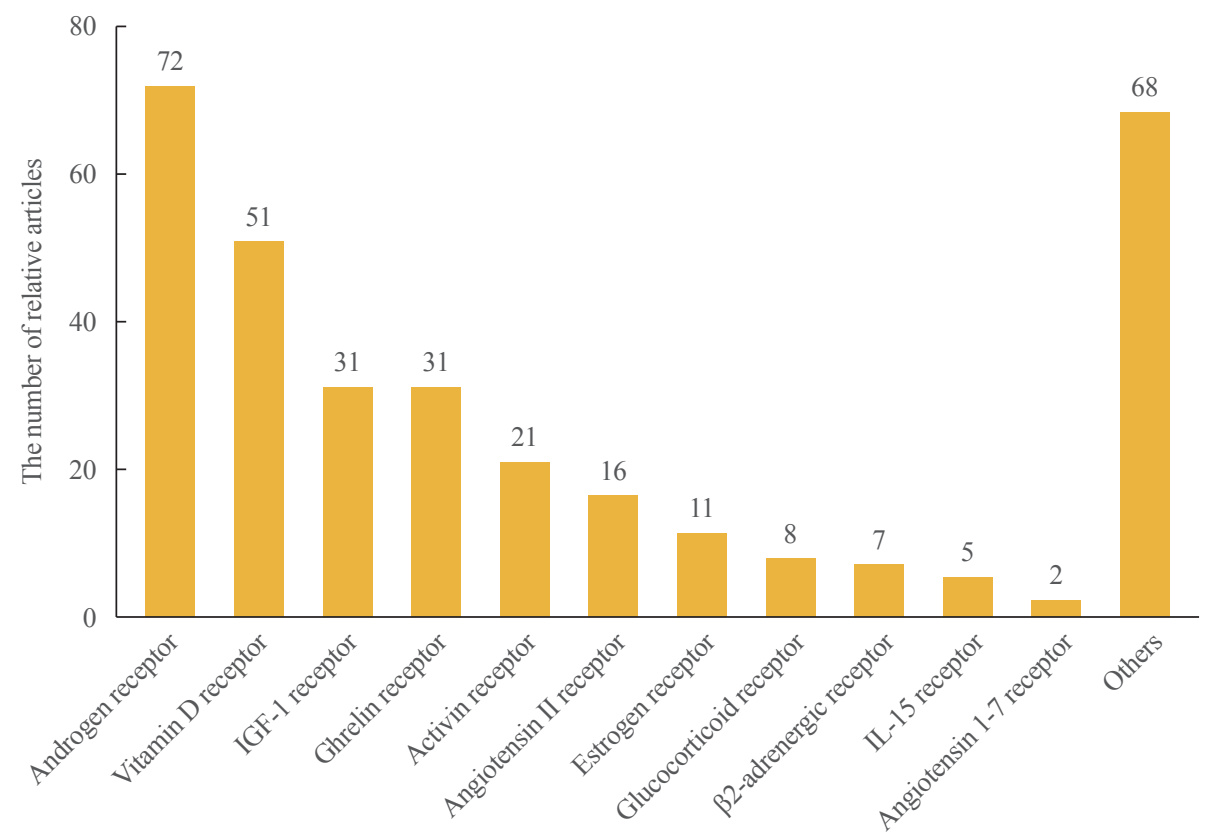

Fig. 3. The current status of articles on sarcopenia and cell signaling receptors. A literature search was conducted in PubMed (keyword: sarcopenia, receptor, and/or related-term) and the relevant data extend up to March 2021. IGF-1, insulin-like growth factor 1; IL-15, interleukin 15.

The etiology of sarcopenia is not completely understood. Therefore, understanding the pathogenic mechanisms and collecting molecular targets should precede attempting pharmacological interventions as a therapeutic strategy. The following section provides a brief overview of the current knowledge of membrane or intracellular signaling receptors used as pharmacological interventions for sarcopenia.

\section{Intracellular receptors}

\section{Androgen receptor}

$\mathrm{AR}$ is a nuclear receptor, and its activity is regulated through the binding of androgenic steroids such as testosterone. Activated $\mathrm{AR}$ is translocated from the cytoplasm into the nucleus [35]. The $A R$ gene is widely expressed in cells and tissues in the skeletal muscle environment, including myoblasts, myofibers, and satellite cells [36]. In normal men, androgens increase the level of circulating IGF-1, which is a powerful anabolic agent in muscles [37].

Testosterone is a major androgen secreted endogenously that interacts with skeletal muscle cells through binding to ARs. Testosterone levels gradually decrease after 30 years of age, and this decrease is associated with a decline in muscle mass and strength [38,39]. Furthermore, testosterone promotes regeneration by activating satellite cells [40]. Although there are side effects such as erythrocytosis and cardiovascular risk [41,42], few thromboembolic events have been reported in the literature, and the European Medicines Agency announced that "there is no consistent evidence that testosterone products have increased cardiovascular risk" $[43,44]$. Thus, testosterone therapy may be beneficial for those who have symptoms of low muscle mass and function caused by testosterone deficiency.

Selective androgen receptor modulators (SARMs) are a type of non-steroidal ligands that have an affinity for AR and exhibit anabolic properties specifically in muscles. SARMs were developed to avoid the side effects of androgens while taking advantage of the anabolic effects of AR agonists [45-47]. GTx-024 and MK-0773 are non-steroidal SARMs. Although not specifically targeted for sarcopenia, GTX-024 was evaluated as a potential treatment for muscle wasting and cachexia in completed phase 2 and 3 trials (NCT00467844; 2007, NCT01355497; 2011) [48, 49]. The GTx-024 group exhibited a significant increase in total lean mass. In a phase 2 trial, treatment with MK-0773 in patients with sarcopenia showed a statistically significant improvement in total lean mass [50]. Therefore, SARMs have the potential to be applied as a treatment for sarcopenia.

\section{Vitamin $D$ receptor}

VDR is a member of the nuclear receptor family and acts as a ligand-dependent transcription factor. When binding to calcitriol, an active metabolite of vitamin D, VDR moves to the nucle- 
us and interacts with retinoid X receptor (RXR) to form heterodimers. The VDR/RXR complex binds to the vitamin D response element and regulates the expression of target genes such as the FOXO1 transcription factor and inhibitor of DNAbinding/differentiation (ID) gene, which is responsible for muscle growth, metabolism, and myoblast differentiation [51,52].

Human muscle immunohistochemistry showed that VDR expression decreased with age [53]. VDR plays a regulatory role in calcium homeostasis [54]. In rats, a diet without vitamin D causes hypocalcemia and muscle protein degradation, which can be partially corrected with calcium supplementation alone [55]. Vitamin D deficiency is associated with a variety of myopathies, including myalgia [56]. The muscle fibers of VDR-null mice were smaller than those of the control group, and the expression of early markers of muscle differentiation, such as myogenic factor 5 (myf5), myogenin, E2A, and early myosin heavy chain isoforms, was aberrantly high and persistent [57]. Myocyte-specific VDR-null mice showed a proportional decrease in lean mass, voluntary wheel-running distance, average running speed, and grip strength [58]. A statistical analysis of randomized controlled trials conducted between 1966 and January 2014 revealed that vitamin D supplementation significantly increased muscle strength, but did not affect muscle mass or muscle power [59].

International clinical practice guidelines for sarcopenia do not recommend vitamin D supplementation to patients with sarcopenia because of the lack of robust evidence [7], and there are no studies showing the results of using vitamin D as a strategy for sarcopenia on ClinicalTrials.gov. Further research on vitamin D and sarcopenia would be useful for formulating a pharmacological strategy.

\section{Membrane receptors IGF-1 receptor}

The IGF-1 receptor (IGF1R) is a transmembrane receptor that is activated by IGF-1 (a growth hormone) and belongs to the large class of tyrosine kinase receptors. Activation of the IGF1R by IGF-1 binding induces multiple signaling pathways, including the phosphoinositide 3-kinase (PI3K)/Akt and mitogen-activated protein kinase (MAPK)/extracellular signal-regulated kinase (ERK) pathways, and leads to muscle hypertrophy through the promotion of anabolic effects [60]. Muscle-specific IGF-1 transgenic mice consistently showed persistent muscle hypertrophy [61]. Serum IGF-1 levels decrease during aging, and this decrease is associated with a variety of pathological conditions, including chronic disease, inflammation, and malnutrition
$[62,63]$. In experimental muscle atrophy models such as dexamethasone-injected mice, muscular dystrophy, and hind limb suspension, local overexpression of IGF-1 was able to restore the weakened muscle [64-66]. In addition, adeno-associated virus-mediated IGF-1 gene transfer blocked aging-related muscle atrophy in old mice [67]. Because IGF-1 production is promoted by growth hormone, the side effects of IGF-1 may be similar to those from the abuse of other growth hormones. Lipohypertrophy and erythema at the injection site are very frequent side effects $[68,69]$. Other negative symptoms reported after administration of recombinant human IGF-I include myalgia, edema, hypoglycemia, seizures, jaw pain, headaches, altered liver function, and increased liver and kidney mass [69-72].

In the clinical stage, a phase 2 randomized clinical trial evaluating the efficacy of IGF-1 involved administering subcutaneous injections once daily for 6 months to boys with Duchenne muscular dystrophy [73]. The 6-minute walking distance change increased by $3.4 \mathrm{~m}$ in the IGF-1 treatment group and decreased by $5.1 \mathrm{~m}$ in the control group. The height velocity in the IGF-1 treatment group was $2.6 \mathrm{~cm} /$ year, and that in the control group was $-0.06 \mathrm{~cm} /$ year (NCT01207908). More clinical studies are needed to determine whether IGF-1 administration could be a safe and effective therapeutic strategy for sarcopenia.

\section{Ghrelin receptor}

The ghrelin receptor is a seven-transmembrane GPCR that binds to growth hormone secretagogues (GHS) such as ghrelin. Ghrelin receptor expression occurs mainly in the brain, but lower levels are also found in the skeletal muscle and heart, as well as in peripheral organs such as the pancreas, spleen, kidneys, and adrenal glands [74,75]. Ghrelin is important for food intake, weight control, and glucose homeostasis. Ghrelin administration promotes the synthesis of nitric oxide and central regulation of food intake in the hypothalamus [76].

Although the level of muscle GHS receptors (GHSRs) is low, ghrelin exhibits anabolic properties in skeletal muscle. Ghrelin prevents muscle atrophy induced by cisplatin treatment or tumor implantation by upregulating AKT, MyoD, and myogenin and by inhibiting inflammatory cytokines, p38-CCAAT/enhancer binding proteins- $\beta$ (C/EBP- $\beta)$, and myostatin [77]. Ghrelin levels are generally lower in elderly adults than in middleaged adults. Elderly individuals with sarcopenia showed significantly lower ghrelin levels than those without sarcopenia [78]. In old mice, genetic deficiency of ghrelin showed an acceleration of fasting-induced muscle atrophy and a decrease in the percentage of lean mass and wheel running distance [79]. In 
healthy elderly individuals, the oral administration of ibutamoren (MK-677), a non-peptide agonist of ghrelin receptors, increased serum growth hormone and IGF-1 levels without serious side effects, but failed to induce a body weight increase [80]. A phase 2 study showed that anamorelin, a GHSR agonist, improved lean body mass, performance status, and quality of life in patients with non-small cell lung cancer [81].

Overall, ghrelin and other small molecule agonists of the ghrelin receptor increase food intake and stimulate muscle anabolic action. Therefore, these could be attractive candidates for the treatment of sarcopenia.

\section{Activin type II receptors}

The activin type II receptors (ActRIIA or ActRIIB) belong to the larger transforming growth factor- $\beta$ (TGF- $\beta$ ) receptor family. These receptors are involved in a variety of physiological and cellular processes including embryonic development and cellular homeostasis [82]. The myostatin/activin type IIB receptor pathway is a major signaling pathway that regulates muscle growth and maintenance $[83,84]$. In the membrane, the binding of ActRIIB to its natural ligands such as activin, myostatin, and growth differentiation factor 11 (GDF11) activates the activin receptor-like kinase (ALK4 or ALK5), and then leads to the phosphorylation of SMAD2/3. Phosphorylated SMAD2/3 forms a heterotrimeric complex with SMAD4 to regulate gene expression and intracellular signaling $[85,86]$. Activation of SMAD2/3 signaling leads to inactivation of AKT signaling and subsequent dephosphorylation of FOXO3, which not only inhibits protein synthesis, but also promotes proteolysis through the ubiquitin-proteasome system [87,88].

Myostatin, known as GDF8, is a member of the TGF- $\beta$ superfamily and is a molecular target that has been intensively studied for muscle wasting disorders. Myostatin is mainly expressed in cells of the skeletal muscle lineage and inhibits the growth and differentiation of muscle cells [89-91]. Overexpression of the myostatin gene in mice caused skeletal muscle atrophy [92], while pharmacological and genetic blockade of ActRIIB induced muscle hypertrophy in mice [93]. Patients without mature myostatin caused by genetic mutations have been shown to have increased muscle mass and strength [94].

The first human trial of myostatin inhibitors was to evaluate the efficacy of stamulumab (MYO-029) in patients with muscular dystrophy. The phase 2 clinical trial failed to show efficacy for increasing muscle strength and the study was discontinued [95]. Bimagrumab (BYM-338) is a human monoclonal antibody with a high affinity for ActIIRB and inhibits downstream signal- ing by preventing ligand-receptor binding. A phase 2 study to determine the effectiveness of BYM-338 in elderly with sarcopenia and mobility restrictions showed that 16 weeks of BYM338 treatment increased skeletal muscle mass and strength and improved mobility (NCT01601600) [13]. Since then, Novartis conducted a phase 2 clinical trial to confirm the safety and efficacy of bimagrumab with adequate nutrition and light exercise (NCT02333331). Six months of bimagrumab treatment showed good safety, increased lean body mass, and reduced fat mass, but there was no significant difference in physical performance [14].

In the meantime, numerous myostatin inhibitory agents have been developed (domagrozumab [PF-06252616], landogrozumab [LY-2495655], trevogrumab [REGN-1033], ramatercept [ACE-031], and ACE-083). Many of them have progressed to human trials [96]. Inhibition of ActRIIB-related ligands has been reported to induce beneficial hypertrophy in muscles, but it can cause serious side effects on other tissues. Overexpression of follistatin (FST), an myostatin (MSTN)/GDF11 inhibitor, reduced bone mineral density and induced tibia fracture in mice [97]. Administration of ACE-031 to boys with Duchenne muscular dystrophy has shown a potential risk of epistaxis and telangiectasia [98].

Activin and bone morphogenetic protein (BMP) are expressed in a variety of tissues, including muscle, and regulate the development of many cell types. These members of the TGF- $\beta$ family, including myostatin, have high similarities in their recognition sites, indicating that inhibition of one of these ligands may cause unwanted side effects in other tissues [96]. In fact, several myostatin inhibitors have cross-reactivity with activin A, BMPs, and GDF11 [99]. Therefore, the study of drug delivery systems for precise targeting would be helpful for the development of myostatin-related drugs.

\section{Angiotensin II receptor}

Angiotensin II receptor type 1 (AGTR1 or AT1) is a member of the $\mathrm{G}$ protein-coupled receptor family, and angiotensin II, a ligand of AGTR1, is an important bioactive molecule of the renin-angiotensin system, which manages blood pressure, fluid retention, and electrolyte balance [100]. Disruption of the $\mathrm{Ag}$ trla gene, which encodes AT1A, prolongs the lifespan of mice through the prevention of cardiac hypertrophy and fibrosis [101], and pharmacological blockade of AGTR1 improves muscle repair and regeneration by inhibiting the activity of the C1q-Wnt/ $\beta$-catenin signaling pathway and canonical TGF- $\beta$ signaling pathway [102-104]. However, persistent and exces- 
sive activation of AGTR1 causes a variety of age-related diseases such as cardiovascular disease [105].

Inhibitors of angiotensin-converting enzyme (ACE), which plays a role in converting angiotensin I to angiotensin II, have been mainly used as primary and secondary prophylactic treatments for cardiovascular disease [106]. ACE inhibitors are known to increase the level of IGF-I, a hormone that stimulates muscle growth, and the number of mitochondria [107], suggesting beneficial effects of ACE inhibitors on sarcopenia. Perindopril, a long-acting ACE inhibitor, improved walking distance and reduced hip fracture in elderly individuals with vascular diseases $[108,109]$. In addition, treatment of losartan, a selective and competitive AGTR1 antagonist, resulted in a reduction of serum TGF- $\beta 1$ levels and subsequent inhibition of SMAD2/3 activity, leading to muscle remodeling and functional recovery in sarcopenic mice [104,110]. In humans, a phase 2 trial of losartan for the prevention of sarcopenia has been completed (NCT01989793). However, the results have not yet been reported. Additional evidence should be provided before recommending ACE inhibitors or ATR antagonists to prevent sarcopenia.

\section{CONCLUSIONS}

Sarcopenia patients have health problems related to physical activity and comorbidities such as osteoporosis, obesity, diabetes, and cognitive disorders $[8,111]$. There is no U.S. Food and Drug Administration-approved drug for sarcopenia to date, and nonpharmacological interventions such as resistance training and nutritional supplementation are common and applicable alternative strategies.

Pharmacological interventions such as myostatin inhibitors, testosterone, and SARMs clinically show the potential to prevent sarcopenia. However, they have not been successful in terms of safety due to erythrocytosis, cardiovascular risk, epistaxis, and telangiectasis. As sarcopenia treatment requires longterm therapy, safety issues should be considered very carefully. Although not covered in this paper, targeting the Mas receptors and ryanodine receptors could be a potential pharmacological strategy. Angiotensin 1-7 peptide, a ligand of the Mas receptor, has a preventive effect on immobilization-induced muscle atrophy [112]. Sarconeos (BIO101), the Mas receptor activator, is undergoing a phase 2 clinical trial (NCT03452488, 2018). Treatment with ARM210 (S48168), a RyR calcium channel stabilizer, improved muscle function and histology in an $M d x$ mouse model without side effects, and a clinical trial has been done but has not been reported yet [113].
Drug delivery systems are an emerging field in sarcopenia drug development. This strategy aims to properly expose the drug to the site of action of skeletal muscle, while sparing unwanted organs [114,115]. Adeno-associated virus, muscle-targeting delivery systems, nanoparticles, and extracellular vesicles are current promising drug delivery systems [116]. Gold nanoparticles conjugated to the IL-4 cytokine are more stable than soluble IL-4 in vitro and exhibit faster muscle regeneration in vivo [117]. Exosome-mediated delivery of myostatin inhibitor showed increased serum stability, delivery efficiency, and regenerative efficacy in $M d x$ mice [118].

The molecular mechanisms of sarcopenia form a very complex network due to simultaneous reactions of multiple risk factors and interactions between elements of the network. Therefore, patient typing with a variety of biomarkers will facilitate drug efficacy, thereby enabling personalized medicine in sarcopenia. Diversified strategies involving combinations of drugs targeting different pathways may also increase the success of interventions for sarcopenia.

\section{CONFLICTS OF INTEREST}

Ki-Sun Kwon also serves as the chief executive officer of Aventi Inc., but does not have any conflicts of interest. Jong-Hyeon Yoon does not have any conflicts of interest to declare.

\section{ACKNOWLEDGMENTS}

This work was supported by grants from the Bio \& Medical Technology Development Program (2017M3A9D8048708, KiSun Kwon) of the National Research Foundation (NRF) funded by the Korean government (Ministry of Science and ICT) and the KRIBB Research Initiative Program.

\section{ORCID}

Jong Hyeon Yoon https://orcid.org/0000-0002-4261-0267

Ki-Sun Kwon https://orcid.org/0000-0002-6401-2735

\section{REFERENCES}

1. Cruz-Jentoft AJ, Sayer AA. Sarcopenia. Lancet 2019;393: 2636-46.

2. Cao L, Morley JE. Sarcopenia is recognized as an independent condition by an International Classification of Disease, Tenth Revision, Clinical Modification (ICD-10-CM) code. 
J Am Med Dir Assoc 2016;17:675-7.

3. Chen LK, Woo J, Assantachai P, Auyeung TW, Chou MY, Iijima K, et al. Asian Working Group for Sarcopenia: 2019 consensus update on sarcopenia diagnosis and treatment. J Am Med Dir Assoc 2020;21:300-7.

4. Cruz-Jentoft AJ, Landi F, Schneider SM, Zuniga C, Arai H, Boirie Y, et al. Prevalence of and interventions for sarcopenia in ageing adults: a systematic review: report of the International Sarcopenia Initiative (EWGSOP and IWGS). Age Ageing 2014;43:748-59.

5. Cruz-Jentoft AJ, Bahat G, Bauer J, Boirie Y, Bruyere O, Cederholm T, et al. Sarcopenia: revised European consensus on definition and diagnosis. Age Ageing 2019;48:1631.

6. Chen LK, Liu LK, Woo J, Assantachai P, Auyeung TW, Bahyah KS, et al. Sarcopenia in Asia: consensus report of the Asian Working Group for Sarcopenia. J Am Med Dir Assoc 2014;15:95-101.

7. Dent E, Morley JE, Cruz-Jentoft AJ, Arai H, Kritchevsky SB, Guralnik J, et al. International Clinical Practice Guidelines for Sarcopenia (ICFSR): screening, diagnosis and management. J Nutr Health Aging 2018;22:1148-61.

8. Kwak JY, Kwon KS. Pharmacological interventions for treatment of sarcopenia: current status of drug development for sarcopenia. Ann Geriatr Med Res 2019;23:98-104.

9. Dao T, Green AE, Kim YA, Bae SJ, Ha KT, Gariani K, et al. Sarcopenia and muscle aging: a brief overview. Endocrinol Metab (Seoul) 2020;35:716-32.

10. Ceglia L, Niramitmahapanya S, da Silva Morais M, Rivas DA, Harris SS, Bischoff-Ferrari H, et al. A randomized study on the effect of vitamin D3 supplementation on skeletal muscle morphology and vitamin D receptor concentration in older women. J Clin Endocrinol Metab 2013;98: E1927-35.

11. Snyder PJ, Bhasin S, Cunningham GR, Matsumoto AM, Stephens-Shields AJ, Cauley JA, et al. Lessons from the testosterone trials. Endocr Rev 2018;39:369-86.

12. Becker C, Lord SR, Studenski SA, Warden SJ, Fielding RA, Recknor CP, et al. Myostatin antibody (LY2495655) in older weak fallers: a proof-of-concept, randomised, phase 2 trial. Lancet Diabetes Endocrinol 2015;3:948-57.

13. Rooks D, Praestgaard J, Hariry S, Laurent D, Petricoul O, Perry RG, et al. Treatment of sarcopenia with bimagrumab: results from a phase ii, randomized, controlled, proof-ofconcept study. J Am Geriatr Soc 2017;65:1988-95.

14. Rooks D, Swan T, Goswami B, Filosa LA, Bunte O, Pan- chaud N, et al. Bimagrumab vs optimized standard of care for treatment of sarcopenia in community-dwelling older adults: a randomized clinical trial. JAMA Netw Open 2020; 3:e2020836.

15. Lee SM, Lee SH, Jung Y, Lee Y, Yoon JH, Choi JY, et al. FABP3-mediated membrane lipid saturation alters fluidity and induces ER stress in skeletal muscle with aging. Nat Commun 2020;11:5661.

16. Kalyani RR, Corriere M, Ferrucci L. Age-related and disease-related muscle loss: the effect of diabetes, obesity, and other diseases. Lancet Diabetes Endocrinol 2014;2:819-29.

17. Jaitovich A, Barreiro E. Skeletal muscle dysfunction in chronic obstructive pulmonary disease: what we know and can do for our patients. Am J Respir Crit Care Med 2018; 198:175-86.

18. Furrer R, Handschin C. Muscle wasting diseases: novel targets and treatments. Annu Rev Pharmacol Toxicol 2019;59: 315-39.

19. Schiaffino S, Dyar KA, Ciciliot S, Blaauw B, Sandri M. Mechanisms regulating skeletal muscle growth and atrophy. FEBS J 2013;280:4294-314.

20. Campins L, Camps M, Riera A, Pleguezuelos E, Yebenes JC, Serra-Prat M. Oral drugs related with muscle wasting and sarcopenia. A review. Pharmacology 2017;99:1-8.

21. Bodine SC, Stitt TN, Gonzalez M, Kline WO, Stover GL, Bauerlein R, et al. Akt/mTOR pathway is a crucial regulator of skeletal muscle hypertrophy and can prevent muscle atrophy in vivo. Nat Cell Biol 2001;3:1014-9.

22. From the American Association of Neurological Surgeons (AANS), American Society of Neuroradiology (ASNR), Cardiovascular and Interventional Radiology Society of Europe (CIRSE), Canadian Interventional Radiology Association (CIRA), Congress of Neurological Surgeons (CNS), European Society of Minimally Invasive Neurological Therapy (ESMINT), et al. Multisociety consensus quality improvement revised consensus statement for endovascular therapy of acute ischemic stroke. Int J Stroke 2018;13:612-32.

23. Ali S, Garcia JM. Sarcopenia, cachexia and aging: diagnosis, mechanisms and therapeutic options: a mini-review. Gerontology 2014;60:294-305.

24. von Haehling S, Steinbeck L, Doehner W, Springer J, Anker SD. Muscle wasting in heart failure: an overview. Int J Biochem Cell Biol 2013;45:2257-65.

25. Wiedmer P, Jung T, Castro JP, Pomatto LC, Sun PY, Davies KJ, et al. Sarcopenia: molecular mechanisms and open questions. Ageing Res Rev 2021;65:101200. 
26. Mankhong S, Kim S, Moon S, Kwak HB, Park DH, Kang JH. Experimental models of sarcopenia: bridging molecular mechanism and therapeutic strategy. Cells 2020;9:1385.

27. Suvarna BS. Drug-receptor interactions. Kathmandu Univ Med J (KUMJ) 2011;9:203-7.

28. Santos R, Ursu O, Gaulton A, Bento AP, Donadi RS, Bologa $\mathrm{CG}$, et al. A comprehensive map of molecular drug targets. Nat Rev Drug Discov 2017;16:19-34.

29. Waller DG, Sampson AP. Medical pharmacology and therapeutics. 5th ed. Edinburgh: Elsevier; 2018. Chapter 1, Principles of pharmacology and mechanisms of drug action; $p$. 3-31.

30. Panyam J, Labhasetwar V. Targeting intracellular targets. Curr Drug Deliv 2004;1:235-47.

31. Lounsbury K. Pharmacology. San Diego: Academic Press; 2009. Chapter 6, Signal transduction and second messengers; p. 103-12.

32. Tamai I, Tsuji A. Transporter-mediated permeation of drugs across the blood-brain barrier. J Pharm Sci 2000;89:137188.

33. Bareford LM, Swaan PW. Endocytic mechanisms for targeted drug delivery. Adv Drug Deliv Rev 2007;59:748-58.

34. Adcock IM. Molecular mechanisms of glucocorticosteroid actions. Pulm Pharmacol Ther 2000;13:115-26.

35. Tien AH, Sadar MD. Keys to unlock androgen receptor translocation. J Biol Chem 2019;294:8711-2.

36. Chen Y, Zajac JD, MacLean HE. Androgen regulation of satellite cell function. J Endocrinol 2005;186:21-31.

37. Hobbs CJ, Plymate SR, Rosen CJ, Adler RA. Testosterone administration increases insulin-like growth factor-I levels in normal men. J Clin Endocrinol Metab 1993;77:776-9.

38. Morley JE. Pharmacologic options for the treatment of sarcopenia. Calcif Tissue Int 2016;98:319-33.

39. Griggs RC, Kingston W, Jozefowicz RF, Herr BE, Forbes G, Halliday D. Effect of testosterone on muscle mass and muscle protein synthesis. J Appl Physiol (1985) 1989;66: 498-503.

40. Serra C, Tangherlini F, Rudy S, Lee D, Toraldo G, Sandor $\mathrm{NL}$, et al. Testosterone improves the regeneration of old and young mouse skeletal muscle. J Gerontol A Biol Sci Med Sci 2013;68:17-26.

41. Grech A, Breck J, Heidelbaugh J. Adverse effects of testosterone replacement therapy: an update on the evidence and controversy. Ther Adv Drug Saf 2014;5:190-200.

42. Coviello AD, Kaplan B, Lakshman KM, Chen T, Singh $\mathrm{AB}$, Bhasin S. Effects of graded doses of testosterone on erythropoiesis in healthy young and older men. J Clin Endocrinol Metab 2008;93:914-9.

43. Tan RS, Salazar JA. Risks of testosterone replacement therapy in ageing men. Expert Opin Drug Saf 2004;3:599-606.

44. Hackett GI. Testosterone replacement therapy and mortality in older men. Drug Saf 2016;39:117-30.

45. Davis MP, Panikkar R. Sarcopenia associated with chemotherapy and targeted agents for cancer therapy. Ann Palliat Med 2019;8:86-101.

46. Narayanan R, Coss CC, Dalton JT. Development of selective androgen receptor modulators (SARMs). Mol Cell Endocrinol 2018;465:134-42.

47. Srinath R, Dobs A. Enobosarm (GTx-024, S-22): a potential treatment for cachexia. Future Oncol 2014;10:187-94.

48. Dobs AS, Boccia RV, Croot CC, Gabrail NY, Dalton JT, Hancock ML, et al. Effects of enobosarm on muscle wasting and physical function in patients with cancer: a doubleblind, randomised controlled phase 2 trial. Lancet Oncol 2013;14:335-45.

49. Crawford J, Prado CM, Johnston MA, Gralla RJ, Taylor RP, Hancock ML, et al. Study design and rationale for the phase 3 clinical development program of enobosarm, a selective androgen receptor modulator, for the prevention and treatment of muscle wasting in cancer patients (POWER trials). Curr Oncol Rep 2016;18:37.

50. Papanicolaou DA, Ather SN, Zhu H, Zhou Y, Lutkiewicz J, Scott BB, et al. A phase IIA randomized, placebo-controlled clinical trial to study the efficacy and safety of the selective androgen receptor modulator (SARM), MK-0773 in female participants with sarcopenia. J Nutr Health Aging 2013;17: 533-43.

51. Wagatsuma A, Sakuma K. Vitamin D signaling in myogenesis: potential for treatment of sarcopenia. Biomed Res Int 2014;2014:121254.

52. Wang TT, Tavera-Mendoza LE, Laperriere D, Libby E, MacLeod NB, Nagai Y, et al. Large-scale in silico and microarray-based identification of direct 1,25-dihydroxyvitamin D3 target genes. Mol Endocrinol 2005;19:2685-95.

53. Bischoff-Ferrari HA, Borchers M, Gudat F, Durmuller U, Stahelin HB, Dick W. Vitamin D receptor expression in human muscle tissue decreases with age. J Bone Miner Res 2004;19:265-9.

54. Tan LJ, Liu SL, Lei SF, Papasian CJ, Deng HW. Molecular genetic studies of gene identification for sarcopenia. Hum Genet 2012;131:1-31.

55. Bhat M, Kalam R, Qadri SS, Madabushi S, Ismail A. Vita- 
min D deficiency-induced muscle wasting occurs through the ubiquitin proteasome pathway and is partially corrected by calcium in male rats. Endocrinology 2013;154:4018-29.

56. Girgis CM, Clifton-Bligh RJ, Hamrick MW, Holick MF, Gunton JE. The roles of vitamin D in skeletal muscle: form, function, and metabolism. Endocr Rev 2013;34:33-83.

57. Endo I, Inoue D, Mitsui T, Umaki Y, Akaike M, Yoshizawa $\mathrm{T}$, et al. Deletion of vitamin $\mathrm{D}$ receptor gene in mice results in abnormal skeletal muscle development with deregulated expression of myoregulatory transcription factors. Endocrinology 2003;144:5138-44.

58. Girgis CM, Cha KM, So B, Tsang M, Chen J, Houweling $\mathrm{PJ}$, et al. Mice with myocyte deletion of vitamin $\mathrm{D}$ receptor have sarcopenia and impaired muscle function. J Cachexia Sarcopenia Muscle 2019;10:1228-40.

59. Beaudart C, Buckinx F, Rabenda V, Gillain S, Cavalier E, Slomian J, et al. The effects of vitamin D on skeletal muscle strength, muscle mass, and muscle power: a systematic review and meta-analysis of randomized controlled trials. J Clin Endocrinol Metab 2014;99:4336-45.

60. Bian A, Ma Y, Zhou X, Guo Y, Wang W, Zhang Y, et al. Association between sarcopenia and levels of growth hormone and insulin-like growth factor-1 in the elderly. BMC Musculoskelet Disord 2020;21:214.

61. Musaro A, McCullagh K, Paul A, Houghton L, Dobrowolny G, Molinaro M, et al. Localized Igf-1 transgene expression sustains hypertrophy and regeneration in senescent skeletal muscle. Nat Genet 2001;27:195-200.

62. Yoshida T, Delafontaine P. Mechanisms of IGF-1-mediated regulation of skeletal muscle hypertrophy and atrophy. Cells 2020;9:1970.

63. Kwak JY, Hwang H, Kim SK, Choi JY, Lee SM, Bang H, et al. Prediction of sarcopenia using a combination of multiple serum biomarkers. Sci Rep 2018;8:8574.

64. Schakman O, Gilson H, de Coninck V, Lause P, Verniers J, Havaux X, et al. Insulin-like growth factor-I gene transfer by electroporation prevents skeletal muscle atrophy in glucocorticoid-treated rats. Endocrinology 2005;146:1789-97.

65. Shavlakadze T, White J, Hoh JF, Rosenthal N, Grounds MD. Targeted expression of insulin-like growth factor-I reduces early myofiber necrosis in dystrophic mdx mice. Mol Ther 2004; 10:829-43.

66. Park S, Brisson BK, Liu M, Spinazzola JM, Barton ER. Mature IGF-I excels in promoting functional muscle recovery from disuse atrophy compared with pro-IGF-IA. J Appl Physiol (1985) 2014;116:797-806.
67. Barton-Davis ER, Shoturma DI, Musaro A, Rosenthal N, Sweeney HL. Viral mediated expression of insulin-like growth factor I blocks the aging-related loss of skeletal muscle function. Proc Natl Acad Sci U S A 1998;95:15603-7.

68. Anderson LJ, Tamayose JM, Garcia JM. Use of growth hormone, IGF-I, and insulin for anabolic purpose: pharmacological basis, methods of detection, and adverse effects. Mol Cell Endocrinol 2018;464:65-74.

69. Williams RM, McDonald A, O’Savage M, Dunger DB. Mecasermin rinfabate: rhIGF-I/rhIGFBP-3 complex: iPLEX. Expert Opin Drug Metab Toxicol 2008;4:311-24.

70. Sullivan DH, Carter WJ, Warr WR, Williams LH. Side effects resulting from the use of growth hormone and insulinlike growth factor-I as combined therapy to frail elderly patients. J Gerontol A Biol Sci Med Sci 1998;53:M183-7.

71. Laron Z. The essential role of IGF-I: lessons from the longterm study and treatment of children and adults with Laron syndrome. J Clin Endocrinol Metab 1999;84:4397-404.

72. Major JM, Laughlin GA, Kritz-Silverstein D, Wingard DL, Barrett-Connor E. Insulin-like growth factor-I and cancer mortality in older men. J Clin Endocrinol Metab 2010;95: 1054-9.

73. Liew WK, Kang PB. Recent developments in the treatment of Duchenne muscular dystrophy and spinal muscular atrophy. Ther Adv Neurol Disord 2013;6:147-60.

74. Gnanapavan S, Kola B, Bustin SA, Morris DG, McGee P, Fairclough P, et al. The tissue distribution of the mRNA of ghrelin and subtypes of its receptor, GHS-R, in humans. J Clin Endocrinol Metab 2002;87:2988.

75. Guan XM, Yu H, Palyha OC, McKee KK, Feighner SD, Sirinathsinghji DJ, et al. Distribution of mRNA encoding the growth hormone secretagogue receptor in brain and peripheral tissues. Brain Res Mol Brain Res 1997;48:23-9.

76. Gaskin FS, Farr SA, Banks WA, Kumar VB, Morley JE. Ghrelin-induced feeding is dependent on nitric oxide. Peptides 2003;24:913-8.

77. Chen JA, Splenser A, Guillory B, Luo J, Mendiratta M, Belinova B, et al. Ghrelin prevents tumour- and cisplatininduced muscle wasting: characterization of multiple mechanisms involved. J Cachexia Sarcopenia Muscle 2015;6: 132-43.

78. Collden G, Tschop MH, Muller TD. Therapeutic potential of targeting the ghrelin pathway. Int J Mol Sci 2017;18:798.

79. Wu CS, Wei Q, Wang H, Kim DM, Balderas M, Wu G, et al. Protective effects of ghrelin on fasting-induced muscle atrophy in aging mice. J Gerontol A Biol Sci Med Sci 2020; 
75:621-30.

80. Nass R, Pezzoli SS, Oliveri MC, Patrie JT, Harrell FE Jr, Clasey JL, et al. Effects of an oral ghrelin mimetic on body composition and clinical outcomes in healthy older adults: a randomized trial. Ann Intern Med 2008;149:601-11.

81. Takayama K, Katakami N, Yokoyama T, Atagi S, Yoshimori K, Kagamu H, et al. Anamorelin (ONO-7643) in Japanese patients with non-small cell lung cancer and cachexia: results of a randomized phase 2 trial. Support Care Cancer 2016;24:3495-505.

82. Gordon KJ, Blobe GC. Role of transforming growth factorbeta superfamily signaling pathways in human disease. Biochim Biophys Acta 2008;1782:197-228.

83. Rooks DS, Laurent D, Praestgaard J, Rasmussen S, Bartlett M, Tanko LB. Effect of bimagrumab on thigh muscle volume and composition in men with casting-induced atrophy. J Cachexia Sarcopenia Muscle 2017;8:727-34.

84. Elkina Y, von Haehling S, Anker SD, Springer J. The role of myostatin in muscle wasting: an overview. J Cachexia Sarcopenia Muscle 2011;2:143-51.

85. Park HM. Current status of sarcopenia in Korea: a focus on Korean geripausal women. Ann Geriatr Med Res 2018;22: 52-61.

86. Sartori R, Gregorevic P, Sandri M. TGF $\beta$ and BMP signaling in skeletal muscle: potential significance for muscle-related disease. Trends Endocrinol Metab 2014;25:464-71.

87. Amirouche A, Durieux AC, Banzet S, Koulmann N, Bonnefoy R, Mouret C, et al. Down-regulation of Akt/mammalian target of rapamycin signaling pathway in response to myostatin overexpression in skeletal muscle. Endocrinology 2009; 150:286-94.

88. Chen JL, Colgan TD, Walton KL, Gregorevic P, Harrison CA. The TGF- $\beta$ signalling network in muscle development, adaptation and disease. Adv Exp Med Biol 2016;900:97131.

89. McPherron AC, Lee SJ. Double muscling in cattle due to mutations in the myostatin gene. Proc Natl Acad Sci U S A 1997;94:12457-61.

90. Thomas M, Langley B, Berry C, Sharma M, Kirk S, Bass J, et al. Myostatin, a negative regulator of muscle growth, functions by inhibiting myoblast proliferation. J Biol Chem 2000;275:40235-43.

91. Rios R, Carneiro I, Arce VM, Devesa J. Myostatin is an inhibitor of myogenic differentiation. Am J Physiol Cell Physiol 2002;282:C993-9.

92. Wagner KR, McPherron AC, Winik N, Lee SJ. Loss of myostatin attenuates severity of muscular dystrophy in $\mathrm{mdx}$ mice. Ann Neurol 2002;52:832-6.

93. Lee SJ, Huynh TV, Lee YS, Sebald SM, Wilcox-Adelman $\mathrm{SA}$, Iwamori N, et al. Role of satellite cells versus myofibers in muscle hypertrophy induced by inhibition of the myostatin/activin signaling pathway. Proc Natl Acad Sci U S A 2012;109:E2353-60.

94. Schuelke M, Wagner KR, Stolz LE, Hubner C, Riebel T, Komen W, et al. Myostatin mutation associated with gross muscle hypertrophy in a child. N Engl J Med 2004;350: 2682-8.

95. Singh P, Rong H, Gordi T, Bosley J, Bhattacharya I. Translational pharmacokinetic/pharmacodynamic analysis of MYO-029 antibody for muscular dystrophy. Clin Transl Sci 2016;9:302-10.

96. Suh J, Lee YS. Myostatin inhibitors: panacea or predicament for musculoskeletal disorders? J Bone Metab 2020; 27:151-65.

97. Suh J, Kim NK, Lee SH, Eom JH, Lee Y, Park JC, et al. GDF11 promotes osteogenesis as opposed to MSTN, and follistatin, a MSTN/GDF11 inhibitor, increases muscle mass but weakens bone. Proc Natl Acad Sci U S A 2020;117: 4910-20.

98. Campbell C, McMillan HJ, Mah JK, Tarnopolsky M, Selby $\mathrm{K}$, McClure T, et al. Myostatin inhibitor ACE-031 treatment of ambulatory boys with Duchenne muscular dystrophy: results of a randomized, placebo-controlled clinical trial. Muscle Nerve 2017;55:458-64.

99. Pirruccello-Straub M, Jackson J, Wawersik S, Webster MT, Salta L, Long K, et al. Blocking extracellular activation of myostatin as a strategy for treating muscle wasting. Sci Rep 2018;8:2292.

100. Benigni A, Cassis P, Remuzzi G. Angiotensin II revisited: new roles in inflammation, immunology and aging. EMBO Mol Med 2010;2:247-57.

101. Benigni A, Corna D, Zoja C, Sonzogni A, Latini R, Salio M, et al. Disruption of the Ang II type 1 receptor promotes longevity in mice. J Clin Invest 2009;119:524-30.

102. Yabumoto C, Akazawa H, Yamamoto R, Yano M, KudoSakamoto Y, Sumida T, et al. Angiotensin II receptor blockade promotes repair of skeletal muscle through down-regulation of aging-promoting C1q expression. Sci Rep 2015;5: 14453.

103. Heisterberg MF, Andersen JL, Schjerling P, Bulow J, Lauersen JB, Roeber HL, et al. Effect of losartan on the acute response of human elderly skeletal muscle to exercise. Med 
Sci Sports Exerc 2018;50:225-35.

104. Burks TN, Andres-Mateos E, Marx R, Mejias R, Van Erp C, Simmers JL, et al. Losartan restores skeletal muscle remodeling and protects against disuse atrophy in sarcopenia. Sci Transl Med 2011;3:82ra37.

105. Kamo T, Akazawa H, Komuro I. Pleiotropic effects of angiotensin II receptor signaling in cardiovascular homeostasis and aging. Int Heart J 2015;56:249-54.

106. Burton LA, Sumukadas D. Optimal management of sarcopenia. Clin Interv Aging 2010;5:217-28.

107. Maggio M, Ceda GP, Lauretani F, Pahor M, Bandinelli S, Najjar SS, et al. Relation of angiotensin-converting enzyme inhibitor treatment to insulin-like growth factor- 1 serum levels in subjects $>65$ years of age (the InCHIANTI study). Am J Cardiol 2006;97:1525-9.

108. Hutcheon SD, Gillespie ND, Crombie IK, Struthers AD, McMurdo ME. Perindopril improves six minute walking distance in older patients with left ventricular systolic dysfunction: a randomised double blind placebo controlled trial. Heart 2002;88:373-7.

109. Peters R, Beckett N, Burch L, de Vernejoul MC, Liu L, Duggan J, et al. The effect of treatment based on a diuretic (indapamide) $+/-$ ACE inhibitor (perindopril) on fractures in the Hypertension in the Very Elderly Trial (HYVET). Age Ageing 2010;39:609-16.

110. Elbaz M, Yanay N, Aga-Mizrachi S, Brunschwig Z, Kassis I, Ettinger K, et al. Losartan, a therapeutic candidate in congenital muscular dystrophy: studies in the $\mathrm{dy}(2 \mathrm{~J}) / \mathrm{dy}(2 \mathrm{~J})$ mouse. Ann Neurol 2012;71:699-708.

111. Kim M, Won CW. Sarcopenia is associated with cognitive impairment mainly due to slow gait speed: results from the Korean Frailty and Aging Cohort Study (KFACS). Int J Environ Res Public Health 2019;16:1491.

112. Aguirre F, Abrigo J, Gonzalez F, Gonzalez A, Simon F, Cabello-Verrugio C. Protective effect of angiotensin 1-7 on sarcopenia induced by chronic liver disease in mice. Int $\mathrm{J}$ Mol Sci 2020;21:3891.

113. Capogrosso RF, Mantuano P, Uaesoontrachoon K, Cozzoli A, Giustino A, Dow T, et al. Ryanodine channel complex stabilizer compound S48168/ARM210 as a disease modifier in dystrophin-deficient mdx mice: proof-of-concept study and independent validation of efficacy. FASEB J 2018;32:1025-43.

114. Ebner DC, Bialek P, El-Kattan AF, Ambler CM, Tu M. Strategies for skeletal muscle targeting in drug discovery. Curr Pharm Des 2015;21:1327-36.

115. Rong S, Wang L, Peng Z, Liao Y, Li D, Yang X, et al. The mechanisms and treatments for sarcopenia: could exosomes be a perspective research strategy in the future? J Cachexia Sarcopenia Muscle 2020;11:348-65.

116. Li Y, Chen M, Zhao Y, Li M, Qin Y, Cheng S, et al. Advance in drug delivery for ageing skeletal muscle. Front Pharmacol 2020;11:1016.

117. Raimondo TM, Mooney DJ. Functional muscle recovery with nanoparticle-directed M2 macrophage polarization in mice. Proc Natl Acad Sci U S A 2018;115:10648-53.

118. Ran N, Gao X, Dong X, Li J, Lin C, Geng M, et al. Effects of exosome-mediated delivery of myostatin propeptide on functional recovery of mdx mice. Biomaterials 2020;236: 119826. 